\title{
Mating system and seedling growth of five tropical tree species
}

\section{Sistema reprodutivo e crescimento de mudas de cinco espécies arbóreas tropicais}

\author{
Vinod Prasad Khanduri ${ }^{1}$
}

\begin{abstract}
Resumo
Um estudo foi feito para determinar o sistema reprodutivo de três espécies arbóreas tropicais entomófilas e duas espécies ornitófilas através de cuzamentos controlados e seu impacto sobre a germinação das sementes. As espécies selecionadas foram Bombax ceiba, Erythrina stricta (ambas ornitófilas), Lagerstroemia speciosa, Mesua ferrea e Schima wallichii (todas entomófilas). O índice do valor de auto-incompatibilidade (ISI) para as distintas espécies foi de 0,00 para B. ceiba, 0,04 para E. sricta, 0,62 para L. speciosa, 0,60 para $M$. ferrea e 0,48 para $S$. wallichii. Os resultados revelaram que $B$. ceiba e $E$. sricta são espécies auto-incompatíveis, enquanto $L$. speciosa, $M$. ferrea e $S$. wallichii são parcialmente auto-incompatíveis. As sementes produzidas por polinização controlada resultaram em maior germinação de sementes seguidas das sementes desenvolvidas por polinização aberta em todas as espécies estudadas.
\end{abstract}

Palavras-chave: Sistema reprodutivo, auto-fecundação, fecundação cruzada, fertilização floral, depressão de endogamia.

\begin{abstract}
This study was conducted to estimate breeding system through controlled crosses and its impact on seed germination percentage of three entomophilous and two ornithophilous tropical woody taxa. The taxa selected were Bombax ceiba, Erythrina stricta (both ornithophilous), Lagerstroemia speciosa, Mesua ferrea and Schima wallichii (all entomophilous). The index of self incompatibility (ISI) value for different species was 0.00 for $B$. ceiba, 0.04 for $E$. sricta, 0.62 for $L$. speciosa, 0.60 for $M$. ferrea and 0.48 for $S$. wallichii. The results revealed that $B$. ceiba and $E$. sricta are self incompatible species whereas $L$. speciosa, $M$. ferrea and S. wallichii are partially self incompatible. The seeds produced from controlled cross-pollination proclaimed highest seed germination followed by the seeds developed through open pollination in all the study species. Keywords: Breeding system, selfing, outcrossing, flower fertilization, inbreeding depression.
\end{abstract}

\section{INTRODUCTION}

High species richness with low population density is one of the characteristic features of tropical forests (APPANAH, 1981; BAWA et al., 1985). The mating system of tropical tree species of different tropical regions of the world have been studied by several workers (BAWA, 1974; Bawa et al., 1985; BULLOCK, 1985; O'MALLEY; BAWA, 1987; MURAWSKI; HAMRICK, 1991, 1992; SARAIVA et al., 1996; MOMOSE et al., 1998; OLIVEIRA; GIBBS, 2000; GOODWILLIE, 2000; RIBEIRO; LOVATO, 2004; KRISHNAMURTHY et al., 1997; NAGARAJAN et al., 1997; TANDON et al., 2001, 2003; RAO; RAJU, 2002, FERRER et al., 2009). The study of the behaviour of plant mating system is important for acquiring knowledge about the tree inheritance patterns, and for subsequent tree improvement and breeding programmes. Knowledge of the mating system and structure of genetic populations of species are important for managing breeding populations and for designing efficient genetic conservation strategies. The mechanism of pollination among the higher plant groups is highly significant in respect of biological studies in ecology, co-evolution, variation and speciation, classical and applied genetics and plant breeding. Variability is controlled by the breeding system of which pollination mechanism forms an integral component. The principal aim of this study is to acquire detailed knowledge about the breeding system through controlled crosses and germination competence of seeds developed by selfed and cross-pollinated crosses of five important tropical tree species, viz. Bombax ceiba Linn., Erythrina stricta Roxb., Lagerstroemia speciosa (L.) Pers., Mesua ferrea Linn. and Schima wallichii (DC.) Korth. All the study species are economically important as (1) Bombax ceiba (family Bombacaceae): flower bud used as vegetable, presence of floss surrounding the

${ }^{1}$ Associate Professor at Department of Forestry. Mizoram University, Aizawl - Mizoram, India. Presently at Department of Forestry / College of Forestry, Uttarakhand University of Horticulture and Forestry Ranichauri - 249199 - Tehri Garhwal Uttarakhand, India. E-mail: khandurivp@yahoo.com. 
seeds, which is used for making pillows, cushions, wood used in construction of boats, boatyards and canoe and also in matchwood and plywood industry. Seeds yield edible oil. The bark, gum and roots are medicinally useful (JAIN et al., 2009). (2) Erythrina stricta (family Papilionaceae): used medicinally for the treatment of rheumatism, jaundice, bronchitis, fever, skin eruption and wound. Leaves extract contain anti-inflammatory activity (KIRTHIKAR; BASU, 1987). (3) Lagerstroemia speciosa (family Lythraceae): The leaves are medicinally useful that contain antidiabetic, antiobesity and antioxidant activity. Wood is used for construction, boat-building, carts and other timber purposes (SUZUKI et al., 1999; KLEIN et al., 2007). (4) Mesua ferrea (family Guttiferae): Highly medicinal plant known as Cobras Saffron and iron wood tree. Its flower contains several pharmacological activities viz. antiasthmatic, anti-inflammatory, estrogenic and progestational, antispasmodic, antimicrobial and anthelmintic, anticancerous, antioxidant and immunomodulatory (MEHERJI et al., 1978; CHAHAR et al, 2012). (5) Schima wallichii (family Theaceae): a commercial timber tree. Bark contains alkaloid that is used as fish poison and also used for dying. Corollas of the flower are used to treat uterine disorders and hysteria (TAMRAKAR, 1992; LI-ZHEN; LI, 1997). The knowledge about the biology of reproductive systems of the selected five aforesaid tree species is skimpy except for the few studies done by Raju et al. (2005), Khanduri et al. (2013), Khanduri (2014) and Khanduri et al. (2015). Though the taxonomic, ethnobotanical, medicinal and pharmacological extent of the studied tree species were worked by You et al. (2003) for Bombax ceiba, Subhashini et al. (2011) for Erythrina stricta, Chanda et al. (2013) for Mesua ferrea, MISHRA et al. (1990) for Lagerstroemia speciosa and Li-Zhen and Li, (1997) for Schima wallichii, the detailed breeding systems of all the selected species have been ignored repulsively so far. The seed production for these tree species, especially fruitification is less than 50 per cent (in case of Bombax ceiba and Erythrina stricta) and below 70 per cent (in case of Mesua ferrea, Lagerstroemia speciosa and Schima wallichii), which also follows temporal pattern of production (KHANDURI et al., 2015). The present study of controlled crosses would augment fruitification potential in all the five investigated tropical tree species.

\section{MATERIAL AND METHODS}

\section{Study area}

The study was undertaken in the year 2010 and 2011 in a semi-deciduous natural forest at Bethlehem Vengthlang in the district Aizawl, Mizoram, the north eastern hill region (NEH) of India (N $23^{\circ} 43^{\prime} 47.5^{\prime \prime}$ E $92^{\circ} 43^{\prime}$ 53.5"; $900 \mathrm{~m}$ asl.). The forest of Bethlehem Vengthlang is dominated by Anthocephalos cadamba (Roxb.) Bosser, Gmelina arborea Roxb., Schima wallichii, Erythrina stricta in association with Lagerstroemia speciosa, Mesua ferrea, Bombax ceiba and Castenopsis spp.

\section{Mating system}

The assessment of breeding system involved six trees in each species during the flowering time in the year 2010 for Lagerstroemia speciosa, Mesua ferrea and Schima wallichii and in the year 2011 for Erythrina stricta and Bombax ceiba. For this purpose the following treatments were performed: (i) natural pollination, in which flowers were not manipulated and left uncovered during the entire flowering season; (ii) spontaneous self-pollination, in which buds were bagged by fine net throughout the flowering period; (iii) hand self-pollination, in which bagged flowers were hand pollinated with their own pollen; (iv) inter flower hand self-pollination (geitonogamy), in which emasculated isolated flowers were hand pollinated with the pollen of other flowers of the same tree; $(\mathrm{v})$ hand cross-pollination, in which emasculated bagged flowers were pollinated with pollen from other trees (pollen were collected and mixed from five different trees selected randomly in a population at least 250 meters apart and applied by a brush to the stigma of selected flowers); and (vi) apomixis, in which anthers and stigma of buds were clipped. All the aforesaid six treatments were done in each individual selected for every species in a population ( $6 \times 5=30$ individuals). Each treatment was conducted on six inflorescences in each tree with a total of thirty six inflorescences per tree for all six treatments. Fruit-set was calculated by dividing the average number of fruits per inflorescence by the average number of flowers per inflorescence at pollination for each treatment. Fruits developed from each treatment were harvested at maturity. The seed-set percentage was calculated by dividing the average number of seeds per fruit/pod by the average number of ovules per flower for each spe- 
cies in every treatment. The ovule number in all the five species has been determined (KHANDURI et al., 2015). To compare fruit-set among hand-selfed and hand crossed treatments, and among open pollinated and hand-crossed treatments, Chi-square analysis was performed (ZAR 1999) to know the pattern of variability between these treatments. An indirect measure of self-incompatibility was obtained by dividing the average fruit set after hand self-pollination by the average fruit set after hand cross-pollination (ZAPATA; ARROYO, 1978; Lloyd; Schoen, 1992). According to Zapata and Arroyo (1978), the resultant value of index reflects the possibilities as: (i) $>1=$ self compatible; (ii) $>0.2$ and $<1=$ partially self incompatible; (iii) $<0.2=$ Mostly self incompatible; and (iv) $0.0=$ completely self incompatible.

For each species, inbreeding depression was calculated for fruit-set, seed-set and seed germination, using the formula; $\delta=1-\mathrm{W}_{\mathrm{s}} / \mathrm{W}_{\mathrm{o}}$ Where $\delta=$ inbreeding depression, $\mathrm{W}_{\mathrm{s}}=$ the performance of progeny resulted from self-pollination and $\mathrm{W}_{\mathrm{o}}=$ the performance of progeny estimated from cross-pollination (LANDE; SCHEMSKE, 1985). A threshold value for inbreeding depression of $\delta=0.5$, indicates that the selfing is favoured below the value, and above which outcrossing is supported (LANDE; SCHEMSKE, 1985).

\section{Seed germination}

Fruit/pod setting and development on each treatment was recorded at fortnightly interval in case of B. ceiba and E. stricta, whereas after one month interval in M. ferrea, L. speciosa and S. wallichii. This was done because the fruit development period of later three species is 6, 9 and 9 months, respectively. Fruits were harvested at maturity and the seeds were collected manually. Twenty fruits of each treatment from all the six trees were collected for size measurement and the physical features of the fruits/pods/capsules (length, diameter $(\mathrm{cm})$ and weight in $\mathrm{g}$.) and seeds (length/length $\times$ width $(\mathrm{mm})$, number of seeds per fruit/pod/ capsule and 100 seed weight in g.). The germination tests of the seeds developed from self, cross and open pollinated flowers of all species were conducted under laboratory conditions at room temperatures $\left(18.0 \pm 1.25^{\circ} \mathrm{C}\right)$. Thirty seeds of each treatment of each species were taken for germinations tests. Three replicates of each treatment were made and the seeds were placed in the Petri-dishes (10 seeds in each Petri-dish). Petri-dishes with Whatman blotting paper was used as germination media. The germination tests of the seeds were done without any treatment. Running tap water was used to moisten the Whatman paper on Petri dishes so that the germination percentage would be at par to the natural conditions.

\section{RESULTS AND DISCUSSION}

The results of the controlled pollination have been summarized in Table 1. Flowers used to test for apomixis did not set fruit. There was significant differences between hand-selfed and hand-crossed treatments in all five species $\left(\mathrm{x}^{2}=28.42, \mathrm{p}<0.0001\right.$ for B. ceiba, $\mathrm{x}^{2}=25.25, \mathrm{p}<0.0001$ for E. sricta, $\mathrm{x}^{2}=17.54, \mathrm{p}<0.0001$ for L. speciosa, $\mathrm{x}^{2}=18.24, \mathrm{p}<0.0001$ for $\mathrm{M}$. ferrea and $\mathrm{x}^{2}=20.12, \mathrm{p}<0.0001$ for $S$. wallichii). The differences between the open pollinated and hand cross treatments was also significant for the studied species $\left(\mathrm{x}^{2}=14.82, \mathrm{p}<0.001, \mathrm{x}^{2}=8.24, \mathrm{p}<0.005, \mathrm{x}^{2}=7.62, \mathrm{p}<0.006, \mathrm{x}^{2}\right.$ $=10.12, \mathrm{p}<0.001, \mathrm{x}^{2}=10.74, \mathrm{p}<0.001$, respectively for B. ceiba, E. stricta, L. speciosa, M. ferrea and S. wallichii). The index of self incompatibility (ISI) value for different species was 0.00 for $B$. ceiba (constituting completely self incompatible), 0.04 for E. sricta (Mostly self incompatible), 0.62 for $L$. speciosa (partially self incompatible), 0.60 for M. ferrea (partially self incompatible) and 0.48 for $S$. wallichii (partially self incompatible). The results pertaining to inbreeding depression showed that among the partially self incompatible species L. speciosa and M. ferrea supporting selfing whereas S. wallichii favoured slightly outcrossing (Table 2 ).

There was a significant $(\mathrm{p}<0.0001)$ variation in morphological features of fruits and seeds developed from self and cross-pollinated flowers of all five species. The morphological variation in fruits and seeds, and seed germination percentage following self, open and cross-pollination has been presented in Table 3. The variation is nearly two fold in each morphological traits, viz. size and weight of fruits and seeds. Highest seed germination of $92 \%$ was found in cross-pollinated seeds of E. stricta, which was only $24 \%$ in self pollinated seeds. The partially self compatible species, i.e. $S$. wallichii, M. ferrea, and L. speciosa also proclaimed the similar trend, however, the value of germina- 
tion percentage in cross-pollinated seeds was $72.48,66.84$ and $64.92 \%$, respectively. The maximum seed germination following open pollination was recorded as $87.27 \%$ for E. stricta, followed by $66.66 \%$ for S. wallichii, $63.4 \%$ for B. ceiba, $60.54 \%$ for M. ferrea and 53.3\% for L. speciosa (Table 3).

Table 1. Mating system studies in five tropical trees in a natural population at Bethlehem Vengthlang.

Tabela 1. Sistema reprodutivo em cinco espécies arbóreas tropicais numa população em Bethlehem Vengthlang.

\begin{tabular}{|c|c|c|}
\hline Treatments & $\%$ fruit set & $\%$ seed set \\
\hline \multicolumn{3}{|l|}{ Bombax ceiba } \\
\hline Apomixis & 0.00 & 0.00 \\
\hline spontaneous self-pollination & 0.00 & 0.00 \\
\hline Natural pollination & $51.64 \pm 4.95$ & $71.4 \pm 4.16$ \\
\hline Hand self-pollination & 00 & 00 \\
\hline Geitonogamy (by hand) & $3.8 \pm 0.92$ & $40.6 \pm 2.56$ \\
\hline Hand cross-pollination & $70.6 \pm 5.24$ & $82.6 \pm 4.98$ \\
\hline \multicolumn{3}{|l|}{ Erythrina stricta } \\
\hline Apomixis & 0.00 & 0.00 \\
\hline spontaneous self-pollination & 0.00 & 0.00 \\
\hline Natural pollination & $40.24 \pm 3.42$ & $72.6 \pm 6.82$ \\
\hline Hand self-pollination & $1.6 \pm 0.56$ & $16.4 \pm 1.88$ \\
\hline Geitonogamy (by hand) & $2.4 \pm 1.74$ & $58.6 \pm 2.62$ \\
\hline Hand cross-pollination & $42.8 \pm 4.76$ & $70.6 \pm 3.68$ \\
\hline \multicolumn{3}{|l|}{ Lagerstroemia speciosa } \\
\hline Apomixis & 0.00 & 0.00 \\
\hline spontaneous self-pollination & $6.4 \pm 1.14$ & $21.4 \pm 2.72$ \\
\hline Natural pollination & $72.8 \pm 6.64$ & $76.4 \pm 8.54$ \\
\hline Hand self-pollination & $46.6 \pm 4.56$ & $48.2 \pm 4.46$ \\
\hline Geitonogamy (by hand) & $66.4 \pm 5.74$ & $72.8 \pm 7.56$ \\
\hline Hand cross-pollination & $74.6 \pm 8.62$ & $86.4 \pm 7.84$ \\
\hline \multicolumn{3}{|l|}{ Mesua ferrea } \\
\hline Apomixis & 0.00 & 0.00 \\
\hline spontaneous self-pollination & $4.5 \pm 0.98$ & $12.2 \pm 2.12$ \\
\hline Natural pollination & $73.9 \pm 2.90$ & $82.4 \pm 10.28$ \\
\hline Hand self-pollination & $48.4 \pm 5.42$ & $52.8 \pm 2.94$ \\
\hline Geitonogamy (by hand) & $70.4 \pm 6.32$ & $78.4 \pm 9.58$ \\
\hline Hand cross-pollination & $80.6 \pm 7.84$ & $90.4 \pm 9.12$ \\
\hline \multicolumn{3}{|l|}{ Schima wallichii } \\
\hline Apomixis & 0.00 & 0.00 \\
\hline spontaneous self-pollination & $8.8 \pm 1.24$ & $24.6 \pm 2.432$ \\
\hline Natural pollination & $68.2 \pm 5.84$ & $58.8 \pm 8.32$ \\
\hline Hand self-pollination & $36.4 \pm 3.26$ & $33.8 \pm 3.42$ \\
\hline Geitonogamy (by hand) & $60.42 \pm 4.42$ & $50.4 \pm 3.46$ \\
\hline Hand cross-pollination & $76.4 \pm 5.86$ & $70.2 \pm 7.24$ \\
\hline
\end{tabular}

Table 2. Inbreeding depression of self- and cross-sired progeny of five tropical trees.

Tabela 2. Depressão de endogamia de progênie obtida por auto-fecundação e fecundação cruzada em cinco espécies arbóreas tropicais.

\begin{tabular}{lcccc}
\hline \multirow{2}{*}{ Name of species } & \multicolumn{4}{c}{ Inbreeding depression (ठ) } \\
\cline { 2 - 5 } & Fruit set & Seed set & Seed germination & Average \\
\hline Bombax ceiba & 1.0 & 1.0 & 1.0 & 1.0 \\
Erythrina stricta & 0.96 & 0.77 & 0.74 & 0.82 \\
Lagerstroemia speciosa & 0.38 & 0.44 & 0.34 & 0.39 \\
Mesua ferrea & 0.40 & 0.41 & 0.30 & 0.37 \\
Schima wallichii & 0.52 & 0.52 & 0.52 & 0.52 \\
\hline
\end{tabular}


Table 3. Variation in seed germination and physical characteristics of fruit/pods and seeds developed following self, open and cross pollinated flowers.

Tabela 3. Variação na germinação de sementes e características físicas dos frutos/vagens obtidos depois de auto-polinização, polinização aberta e polinização cruzada.

\begin{tabular}{|c|c|c|c|c|c|c|}
\hline Variables & $\begin{array}{l}\text { Size (length/ } \\
\text { Diameter) of } \\
\text { fruit/pod }(\mathrm{cm})\end{array}$ & $\begin{array}{l}\text { Size of seed }(\mathrm{mm}) \\
\text { Length/length } \times \text { Width } \\
(\mathrm{mm})\end{array}$ & $\begin{array}{l}\text { Weight of } \\
\text { fruit }(g)\end{array}$ & $\begin{array}{l}\text { No. of } \\
\text { seeds per } \\
\text { capsule/ } \\
\text { fruit }\end{array}$ & $\begin{array}{l}100 \text { seed } \\
\text { weight }(g)\end{array}$ & $\begin{array}{c}\text { Seed } \\
\text { Germination } \\
(\%)\end{array}$ \\
\hline \multicolumn{7}{|l|}{ Bombax ceiba } \\
\hline \multicolumn{7}{|l|}{ Self pollinated } \\
\hline Open pollinated & $16.4 \pm 0.62$ & $8.2 \pm 0.20$ & $18.8 \pm 0.86$ & $284 \pm 21.05$ & $2.14 \pm 0.16$ & $63.4 \pm 2.46$ \\
\hline Cross pollinated & $16.8 \pm 0.34$ & $8.4 \pm 0.20$ & $19.2 \pm 0.56$ & $306 \pm 23.56$ & $2.60 \pm 0.16$ & $66.40 \pm 2.10$ \\
\hline \multicolumn{7}{|l|}{ Erythrina stricta } \\
\hline Self pollinated & $8.76 \pm 2.78$ & $10.0 \pm 0.36$ & $1.40 \pm 0.38$ & $0.55 \pm 0.15$ & $18.20 \pm 4.60$ & $24.26 \pm 1.62$ \\
\hline Open pollinated & $10.89 \pm 2.44$ & $12.5 \pm 0.28$ & $2.67 \pm 0.56$ & $2.45 \pm 0.55$ & $27.0 \pm 2.48$ & $87.27 \pm 4.56$ \\
\hline Cross pollinated & $11.52 \pm 1.84$ & $18.4 \pm 0.42$ & $2.98 \pm 0.64$ & $2.90 \pm 0.48$ & $29.45 \pm 2.56$ & $92.56 \pm 4.86$ \\
\hline \multicolumn{7}{|c|}{ Lagerstroemia speciosa } \\
\hline Self pollinated & $1.10 \pm 0.20$ & $9.42 \pm 2.00 \times 2.35 \pm 0.36$ & $0.54 \pm 0.18$ & $52.50 \pm 17.44$ & $0.25 \pm 0.10$ & $42.52 \pm 4.14$ \\
\hline Open pollinated & $1.19 \pm 0.27$ & $9.83 \pm 2.20 \times 2.65 \pm 0.59$ & $0.66 \pm 0.14$ & $68.55 \pm 15.33$ & $0.30 \pm 0.12$ & $53.3 \pm 2.56$ \\
\hline Cross pollinated & $1.78 \pm 0.46$ & $10.48 \pm 2.40 \times 3.20 \pm 0.52$ & $0.96 \pm 0.18$ & $84.62 \pm 18.34$ & $0.48 \pm 0.38$ & $64.92 \pm 3.58$ \\
\hline \multicolumn{7}{|l|}{ Mesua ferrea } \\
\hline Self pollinated & $3.1 \pm 0.56$ & $21.4 \pm 2.12$ & $34.20 \pm 2.14$ & $1-4$ & 260 & $46.52 \pm 3.16$ \\
\hline Open pollinated & $3.6 \pm 0.46$ & $27.6 \pm 2.76$ & $36.10 \pm 3.14$ & $1-4$ & 350 & $60.54 \pm 2.16$ \\
\hline Cross pollinated & $4.1 \pm 0.52$ & $30.2 \pm 2.64$ & $39.48 \pm 2.48$ & $1-4$ & 412 & $66.84 \pm 4.16$ \\
\hline \multicolumn{7}{|l|}{ Schima wallichii } \\
\hline Self pollinated & $1.10 \pm 0.24$ & $6.4 \pm 1.24 \times 2.2 \pm 0.42$ & $0.46 \pm .16$ & $9.10 \pm 2.48$ & $0.16 \pm 0.07$ & $34.80 \pm 3.45$ \\
\hline Open pollinated & $1.10 \pm 0.22$ & $7.0 \pm 1.57 \times 2.6 \pm 0.58$ & $0.56 \pm .12$ & $9.55 \pm 2.14$ & $0.20 \pm 0.06$ & $66.66 \pm 4.42$ \\
\hline Cross pollinated & $1.60 \pm 0.32$ & $7.84 \pm 1.34 \times 2.9 \pm 0.42$ & $0.88 \pm .18$ & $10.24 \pm 2.02$ & $0.38 \pm 0.20$ & $72.48 \pm 5.56$ \\
\hline
\end{tabular}

The mating system study of five different tree species revealed that the manipulated cross-pollination proclaimed high fruit and seed setting in all the species, however, the manipulated geitonogamous selfing also resulted high seed setting in S. wallichii, M. ferrea, and L. speciosa which indicates that in natural pollination the possibility of inter-flower selfing in these species within the population would be high. This would be due to three reasons that (i) the species are mostly bee pollinated (Apis bee and Xylocopa bee), (ii) prevailed dichogamy; slightly protandry (S. wallichii) and protogyny (L. speciosa and M. ferrea) and (iii) the species showed asynchronization in flowering among individuals within a population. The other two species, viz. E. stricta and B. ceiba, reveal high outcrossing with very low geitonogamy. Both species are ornithophilous and have shown high synchrony in flowering within population. Birds made frequent inter-tree movements in search of nectar and such foraging behaviour was considered to effect cross-pollination. Nevertheless, birds might also be responsible for inter-flower selfing by foraging nectar from different flowers on one individual tree. The experiment on controlled pollination in this study is supporting the level of viability and variability among the seeds developed from self and cross-pollination. Seed set from cross-pollination proclaimed maximum seed germination in all five species, whereas self pollinated seeds had lowest germination. Seed set from open pollination follows the middle range of germination, as there are always chances of mixed mating in open pollination.

The mating system of $B$. ceiba and E. sricta has been found to be self-incompatible whereas $L$. speciosa, M. ferrea and S. wallichii had indicated to be partially self-incompatible. Self-incompatibility is a well-defined phenomenon in woody species and a variety of studies has shown complete self-incompatibility in Nothofagus menziesii (GODLEY, 1979), Eucalyptus morrisbyi (POTTS; SAVVA, 1988), Discaria toumatou (WEBB, 1985), Pseudowintera colorata (LLOYD; WELLS, 1992), Corokia cotoneaster (WEBB, 1994) Cordyline australis (BEEVER; Parkes, 1996), Metrosideros excelsa (ADAMS et al., 1999), Faidherbia albida (GASSAMA-DIA et al., 2003), Erythrina falcata (ETCHEVERRY; ALEMÁN, 2005), partial self-incompatibility in Butea monosperma (TANDON et al., 2003), Tamarindus indica (DIALLO et al., 2008) and Flourensia cernua (FERRER et al., 2009). Self-compatibility has also been reported for several Eucalyptus spp., viz., E. regnans, E. grandis, and E. cladocalyx (POTTS; SAVVA, 1988; ELLIS; SEDGLEY, 1992) and Balanites aegyptiaca (NDOYE et al., 2004). Relatively low 
fruit setting is common in self-incompatible species (SUTHERLAND, 1986; LARSON; BARRETT, 2000); when quantitative variation in the strength of self-incompatible (variation among plants from being partially self-incompatible to self-compatible) occurs, the species are referred to as partially self-incompatible or pseudo-self-compatible or pseudo self-fertile (LEVIN, 1996).

\section{CONCLUSIONS}

The study revealed that all the analysed species exhibited either partial or complete self-incompatible mating system. B. ceiba and E. stricta maintained very low levels of inbreeding which would allow populations of both species to increase reproductive output to reconcile high regeneration potential. L. speciosa and M. ferrea had partially self-incompatible mating system with a value of inbreeding depression below 0.5 that favoured selfing. This indicates that both species have chances of poor reproductive survival through regeneration in natural population. The inbreeding depression value of $S$. wallichii is above 0.5 , supporting outcrossing, and the species would be capable to maintain new population at the time of colonization through better survival of in-growth.

\section{REFERÊNCIAS BIBLIOGRÁFICAS}

ADAMS, G. S.; GOULD; K. S.; MURRAY, B. G. Floral biology and breeding system of pohutukawa (Metrosideros excelsa, Myrtaceae). New Zealand Journal of Botany, v. 37, n. 4, p. 687-702, 1999.

APPANAH, S. Pollination in Malaysian primary forests. Malaysian Forester, v. 44, p. 37-42, 1981.

BAWA, K. S. Breeding systems of tree species of a lowland tropical community. Evolution, Lancaster, v. 28, n. 1, p. 85-92, 1974.

BAWA, K. S.; PERRY, D. R.; BEACH, J. H. Reproductive biology of tropical lowland rain forest trees. I. Sexual systems and incompatibility mechanisms. American Journal of Botany, Columbus, v. 72, n. 3, p. 331-345, 1985.

BEEVER, R. E.; PARKES, S. L. Self-incompatibility in Cordyline australis (Asteliaceae). New Zealand Journal of Botany, v. 34, n. 1, p. 135-137, 1996.

BULLOCK, S. H. Breeding systems in the flora of a tropical deciduos forest in Mexico. Biotropica, Lawrence, v. 17, n. 4, p. 287-301, 1985.

CHAHAR, M. K.; KUMAR, S. D. S.; LOKESH, T.; MANOHARA, K. P. In-vivo antioxidant and immunomodulatory activity of mesuol isolated from Mesua ferrea L. seed oil. International Journal of Immunopharmacology, v. 13, n. 4, p. 386-391, 2012.

CHANDA, S.; RAKHOLIYA, K.; PAREKH, J. Indian medicinal herb: Antimicrobial efficacy of Mesua ferrea L. seed extracted in different solvents against infection causing pathogenic strains. Journal of Acute Disease, $\mathrm{v}$. 2, n. 4, p. 277-281, 2013.

DIALLO, B. O.; MCKEY, D.; CHEVALLIER, M. H.; JOLY, H. I.; HOSSAERT-MCKEY, M. Breeding system and pollination biology of the semidomesticated fruit tree, Tamarindus indica L. (Leguminosae: Caesalpinioideae): Implications for fruit production, selective breeding, and conservation of genetic resources. African Journal of Biotechnology, v. 7, n. 22, p. 4068-4075, 2008.

ELLIS, M.; SEDGLEY, M. Floral morphology and breeding system of three species of Eucalyptus, Section Bisectaria (Myrtaceae). Australian Journal of Botany, v. 40, p. 249-262, 1992.

ETCHEVERRY, A. V.; ALEMÁN, C. E. T. Reproductive biology of Erythrina falcata (Fabaceae: Papilionoideae). Biotropica, Lawrence, v. 37, n. 1, p. 54-63, 2005. 
FERRER, M. M.; GOOD-AVILA, S. V.; MONTAN A, C.; DOMINGUEZ, C. A.; EGUIARTE, L. E. Effect of variation in self-incompatibility on pollen limitation and inbreeding depression in Flourensia cernua (Asteraceae) scrubs of contrasting density. Annals of Botany, Oxford, v. 103, n. 7, p. 1077-1089, 2009.

GASSAMA-DIA, Y. K.; SANÉ, D.; N'DOYE, M. Reproductive biology of Faidherbia albida (Del.) A. Chev. Silva Fennica, Vantaa, v. 37, n. 4, p. 429-436, 2003.

GODLEY, E. J. Flower biology in New Zealand. New Zealand Journal of Botany, v. 17, n. 4, p. 441-466, 1979.

GOODWILLIE, C. Inbreeding depression and mating systems in two species of Linanthus (Polemoniaceae). Heredity, Edinburg, v. 84, n. 3, p. 283-293, 2000.

JAIN, V.; VERMA, S. K.; KATEWA, S. S. Myths, traditions and fate of multipurpose Bombax ceiba L. An appraisal. Indian Journal of Traditional Knowledge, v. 8, n. 4, p. 638-644, 2009.

KHANDURI, V. P. Annual variation in floral phenology and pollen production in Lagerstroemia speciosa: an entomophilous tropical tree. Songklanakarin Journal of Science and Technology, v. 36, n. 4, p. 389-396, 2014.

KHANDURI, V. P.; KUMAR, K. S.; SHARMA, C. M. Role of pollen production in mating success in some tropical tree species. Brazilian Journal of Botany, v. 38, n. 1, p. 107-112, 2015,

KHANDURI, V. P.; SHARMA, C. M.; KUMAR, K. S.; GHILDIYAL, S. K. Annual variation in flowering phenology, pollination, mating system and pollen yield in two natural populations of Schima wallichii (D.C.) Korth. The Scientific World Journal, v. 2013, p. 1-11, 2013.

KIRTHIKAR, K. R.; BASU, B. D. Indian Medicinal Plants, 2.ed. Dehradun: International Book Distributors, 1987. 767 p.

KLEIN, G.; KIM, J.; HIMMELDIRK, K.; CAO, Y.; CHEN, X. Antidiabetes and Anti-obesity Activity of Lagerstroemia speciosa. Evidence-Based Complementary and Alternative Medicine, v. 4, n. 4, p. 401-407, 2007.

KRISHNAMURTHY, K. S.; UMA SHAANKER, R.; GANESHAIAH, K. N. Seed abortion in an animal dispersed species, Syzgium cuminii (L.) Skeels (Myrtaceae): the chemical basis. Current Science, v. 73, n. 10, p. 869-873, 1997.

LANDE, R.; SCHEMSKE, D. W. The evolution of self-fertilization and inbreeding depression in plants. 1. Genetic models. Evolution, Lancaster, v. 39, n. 1, p. 24-40, 1985.

LARSON, B. M. H.; BARRETT, S. C. H. A comparative analysis of pollen limitation in flowering plants. Biological Journal of the Linnean Society, v. 69, n. 4, p. 503-520, 2000.

LEVIN, D. A. The evolutionary significance of pseudo self-fertility. The American Naturalist, Chicago, v. 148, n. 2, p. 321-332, 1996.

LI-ZHEN, W.; LI, Z. W. Study on applied effectiveness of biological firebreak network of Schima," Scientia Silvae Sinicae, v. 33, n. 4, p. 338-348, 1997.

LLOYD, D. G.; SCHOEN, D. J. Self- and cross-fertilization in plants. I. Functional dimensions. International Journal of Plant Science, v. 153, n. 3, p. 358-369, 1992.

LLOYD, D. G.; WELLS, M. S. Reproductive biology of a primitive angiosperm Pseudowintera colorata (Winteraceae), and the evolution of pollination systems in the Anthophyta. Plant Systematics and Evolution, v. 181, n. 1, p. 77-95, 1992. 
Khanduri. - Mating system and seedling growth of five tropical tree species

MEHERJI, P. K.; CHETYE, T. A.; MUNSHI, S. R.; VAIDYA, R. A.; ANTARKAR, D. S.; KOPPIKAR, S. Screening of Mesua ferrea Linn. (nagkeshar) for estrogenic and progestational activity in human and experimental models. Indian Journal of Experimental Biology, v. 16, n. 8, p. 932-933, 1978.

MISHRA, Y.; KHAN, M.S.Y.; ZAFAR, R.; AGARWAL, S.S. Hypoglycaemic activity of leaves of Lagestroemia speciosa (L) Pers. Indian Journal of Pharmacology, v. 22, p. 174-176, 1990.

MOMOSE, K.; YUMOTO, T.; NAGAMITSU, T.; KATO, M.; NAGAMASU, H.; SAKAI, S. Pollination biology in a lowland dipterocarp forest in Sarawak, Malaysia. I. Characteristics of the plant-pollinator community in a lowland dipterocarp forest. American Journal of Botany, Columbus, v. 85, n. 10, p. 1477-1501, 1998.

MURAWSKI, D. A.; HAMRICK, J. L. Mating system and phenology of Ceiba pentandra (Bombacaceae) in Central Panama. Journal of Heredity, Washington, v. 83, n. 6, p. 401-404, 1992.

MURAWSKI, D. A.; HAMRICK, J. L. The effect of the density of flowering individuals on the mating systems of nine tropical tree species. Heredity, Edinburg, v. 67, p. 167-174, 1991.

NAGARAJAN, B.; MANDAL, A. K.; VERMA, R. K.; MAHADEVAN, N. P. Phenology and Controlled Pollination Studies in Tamarind. Silvae Genetica, Frankfurt, v. 47, n. 5-6, p. 237-241, 1997.

NDOYE, M.; DIALLO, I., GASSAMA DIA, Y. K. Reproductive biology in Balanites aegyptiaca (L.) Del., a semiarid forest tree. African Journal of Biotechnology, v. 3, n. 1, p. 40-46, 2004.

OLIVEIRA, P. E.; GIBBS, P. E. Reproductive biology of woody plants in a Cerrado community of Central Brazil. Flora, Holzwiesenstr, v. 195, n. 4, p. 311-329, 2000.

O'MALLEY, D. M.; BAWA, K. S. Mating system of a tropical rain forest tree species. American Journal of Botany, Columbus, v. 74, n. 8, p. 1143-49, 1987.

POTTS, B. M.; SAVVA, M. Self-incompatibility in Eucalyptus. In: KNOX, R. B.; SINGH, M. B.; TROIANI, L. F. (ED.) POLLINATION ‘88. MELBOURN: UNIVERSITY OF MELBOURNE, 1988, P. 165-170.

RAJU, A. J. S.; RAO, S. P.; RANGAIAH, K. Pollination by bats and birds in the obligate outcrosser Bombax ceiba L. (Bombacaceae), a tropical dry season flowering tree species in the Eastern Ghats forests of India. Ornithological Science, v. 4, n. 1, p. 81-87, 2005.

RAO, J. S.; RAJU, A. J. S. Pollination ecology of the Red Sanders Pterocarpus santalinus (Fabaceae), an endemic and endangered tree species. Current Science, v. 83, n. 9, p. 1144-1148, 2002.

RIBEIRO, R. A.; LOVATO, M. B. Mating system in a neotropical tree species, Senna multijuga (Fabaceae). Genetics and Molecular Biology, Ribeirão Preto, v. 27, n. 3, p. 418-424, 2004.

SARAIVA, L. C.; CESAR, O.; MONTEIRO, R. Breeding systems of shrubs and trees of a Brazilian savanna. Arquivos de Biologia e Tecnologia, Curitiba, v. 39, n. 4, p. 751-763, 1996.

SUBHASHINI, N.; PURNIMA, S.; DEVI, J. A. A.; THIRUPATHI, A. T.; LAVANYA, N. Anti-Inflammatory activity of Erythrina stricta Roxb. in Albino Rats. International Journal of PharmTech Research, v. 3, n. 2, p. 1014$1018,2011$.

SUTHERLAND, S. Patterns of fruit-set: What control s fruit-flower ratios in plants? Evolution, Lancaster, v. 40, n. 1 , p. $117-128,1986$.

SUZUKI, Y.; UNNO, T.; USHITANI, M. Antiobesity activity of extracts from Lagerstroemia speciosa L. leaves on female KK-Ay Mice. Journal of Nutrition Science Vitaminology, v. 45, n. 6, p. 791-795, 1999. 
TAMRAKAR, P. R. Management system of natural Schima/Castanopsis forest in the middle hills of Nepal. Banko Jankari, v. 3, n. 2, p. 3-11, 1992.

TANDON, R.; MANOHARA, T. N.; NIJALINGAPPA, B. H. M.; SHIVANNA, K. R. Pollination and pollen-pistil interaction in oil palm, Elaeis guineensis. Annals of Botany, Oxford, v. 87, n. 6, p. 831-838, 2001.

TANDON, R.; SHIVANNA, K. R.; MOHAN RAM, H. Y. Reproductive Biology of Butea monosperma (Fabaceae). Annals of Botany, Oxford, v. 92, n. 5, p. 715-723, 2003.

WEBB, C. J. Pollination, self-incompatibility, and fruit production in Corokia cotoneaster (Escalloniaceae). New Zealand Journal of Botany, v. 32, n. 3, p. 385-392, 1994.

WEBB, C. J. Protandry, pollination, and self-incompatibility in Discaria toumatou. New Zealand Journal of Botany, v. 23, n. 2, p. 331-335, 1985.

YOU, Y. J.; NAM, N. H.; KIM, H. M.; BAE K. H.; AHN, B. Z. Antiangiogenic activity of lupeol from Bombax ceiba. Phytotherpy Research, v. 17, n. 4, p. 341-344, 2003.

ZAPATA, T. R.; ARROYO, M. T. K. Plant reproductive ecology of a secondary deciduous tropical forest in Venezuela. Biotropica, Lawrence, v. 10, n. 3, p. 221-230, 1978.

ZAR, J. Biostatistical Analysis. 4.ed. New Jersey: Prentice-Hall, 1999. 663 p.

Recebido em 01/04/2015

Aceito para publicação em 17/12/2015

Sci. For., Piracicaba, v. 44, n. 110, p. 509-517, jun. 2016 DOI: dx.doi.org/10.18671/scifor.v44n110.23 
